\title{
The (Silent) Articulation of Otherness: Maurice Blanchot's Double Parole in Death Sentence, Awaiting Oblivion, and Madness of the Day
}

\author{
By Alexandra Reuber
}

\begin{abstract}
This article examines Maurice Blanchot's articulation of self vs. other in his novellas, Death Sentence (1948), Awaiting Oblivion (1962), and Madness of the Day (1973). Marked by a fragmented narrative structure and negative discourse, Blanchot's novellas are other as they appear to be incomprehensible and unfinished. Yet, their double parole of saying nothing but everything, allows for his texts to take the form of Levinas's face of the other, a speaking entity that imposes itself onto the (reading) subject and, thus, challenges readers to reflect on the notion of becoming as opposed to being through the engagement with the work.
\end{abstract}

Keywords: Double parole, Face of the other, Negative discourse, Selfhood, Silence

\section{Introduction}

Maurice Blanchot (1907-2003), for as long as he wrote, meditated on selfhood through writing and, by doing so, on writing itself. For Blanchot, writing raised the question of becoming as opposed to the notion of an existing ideal or absolute form of being, thus, nullifying the idea of the completed (literary) text and of the fully developed self.

The author's three novellas, Death Sentence (1948), Awaiting Oblivion (1962), and Madness of the Day (1973), illustrate this annihilation of an existing ideal or absolute form of text and being through non-linear plot outline, lack of fictional visualization, highly fragmented narrative structure, and the abstract use of language. Not the product or completeness of the work but the "quest for the work" is of interest (Blanchot 2003: 200); a quest that expresses itself in an almost incomprehensible, almost negative discourse that is tightly connected to the quest for selfhood and a developing understanding of the self. As a consequence, this lack of completeness of the work, which finds its counterpart in the presence of an insufficiently developed self, often leads to a breakdown of communication between Blanchot's text and reader. In addition, it triggers an apparent silence and an aura of waiting within the text and its fictional characters, as well as between text and reader.

The resulting fragility of the work and the notion of the self then produces an everlasting presence of an inexplicable unknown that neither the reader nor the text ever seems to be able to grasp or define fully. It is a presence that silently points "beyond the borders of the text" (Hill 2012: 143) but somehow cries out from within the work demanding a new beginning of the just ended communication through the (re)examination and (re)evaluation of text, language, and self.

\footnotetext{
*Senior Professor of Practice, Tulane University, USA.
} 
It is only via this double parole that manifests itself in the opposing concepts of communication vs. silence, ending vs. beginning, disappearance vs. reappearance, and presence vs. absence that Blanchot's text and characters come alive, express their own partial truth, formulate their own set of questions, and impose themselves as something other onto the reader. In other words, it is this interplay between the textual source (artistic pole) and the reader (the text's aesthetic pole) that is at the heart of Blanchot's double parole and his literary creations. As a consequence, Blanchot's texts mark the end of communication as the beginning of another discourse that generates new knowledge within the text and one's self; knowledge that can neither be found within the literary artifact, nor gained from a finished text alone. It is the knowledge that can only result from the quest for what is hiding behind the silence of the work: a process that is marked by the dissociation from the textual object and its language whose meaning, as Blanchot explained in his monograph The Work of Fire (1949), "derives not from what exists, but from its own retreat before existence" (1995: 324).

\section{Literature Review}

Literary critics John Gregg, Anne McConnell, Paul Davies, and Ethan Kleinberg, only to name a few, have discussed this juxtaposition of appearance and disappearance, of presence and absence in Blanchot's work. John Gregg, for example, clearly states that in Blanchot's writing "the accent is placed on the way in which something is said and not on what is said," thus, differentiating between the work's "material presence" and its "ideal absence" (1994: 18).

Both Anne McConnell in her monograph Approaching Disappearance (2013) as well as Ethan Kleinberg in his book Generation Existential. Heidegger's Philosophy in France (2005) recognize the domineering notion of absence that marks Blanchot's work. McConnell calls this absence a disappearance, a process that indicates a movement towards nothingness and negation, a process that Blanchot connects with writing itself as it is always "going towards itself, towards its essence, which is disappearance" (Blanchot 2003: 195). Hence, Kleinberg is right stating that in Blanchot's text "the word is both the beginning and the end" (2005: 215).

Through his essay "The Work and the Absence of the Work" (1996), Paul Davies joins this discourse focusing on the process of the disappearing and becoming of the work, a process that is always marked by a present absence or absent presence, by "an obligation to continue writing" (1996: 92), because the idea, the word, yet the entire work is always bound to another idea, word, and work. Hence, any work (silently) articulates its absence, its solitude, its otherness, its constant state of becoming and disappearing.

Yet, despite the fact that Gregg, McConnell, Kleinberg, and Davies recognize the existence of the double parole in Blanchot's work, their critical discourse neither explains its functionality, nor evaluates how this particular "presence of absence" (Gregg 1994: 19) creates meaning itself. Moreover, Gregg, McConnell, Kleinberg, and Davies omit looking at the three novellas Death Sentence (1948), 
Awaiting Oblivion (1962), and Madness of the Day (1973); three literary works that are highly marked by Blanchot's double parole, and which may hold the answer to the understanding of Blanchot's negative discourse and work as a whole. This said, they overlook to ask the following questions: First, what role does Blanchot's negative discourse play in generating this double parole that seems to say nothing but actually expresses everything via a non-explanatory text that demands the reader's cooperation at all times and only comes alive through the reading process? ${ }^{1}$ Second, what knowledge does the reader gain from engaging with an unfinished and highly fragmented text that seems to be incoherent to the degree of being incomprehensible? Third, what broader implications does the recognition of the existing double parole have for Blanchot's work as well as for us readers?

\section{Methodology}

A Levinasian reading of Blanchot's novellas shall answer the questions raised above by examining the following: First, how Blanchot's negative discourse allows for a double parole to occur and for the text to take the form of the face of the other-a speaking entity-that according to Emmanuel Levinas (1906-1995) imposes itself onto the listener, in our case, the reader. Second, how the author's desubjectivized narrators fuel the text's double parole all the while insinuating that the truth of the text is to be found neither in the plot, nor in its words but only in "the silence of essence, essence or essencing (Wesen) that resounds in [each] poetic word" (Llewelyn 2008: 134) and that resonates in the reader through his or her engagement with the text. Third, how Blanchot's textual fragments create an experience of the Levinasian il y a that fosters "the secret of the birth (connaissance) of thought" (Levinas 1987: 125) in the text, and allows the reader to develop a better understanding of the self as well as of "the face that speaks" (Levinas 1987: 120), the textual artifact, through active engagement with the text.

\section{Analysis and Discussion}

\section{Maurice Blanchot and Emmanuel Levinas: Encountering the Face of the Other}

When discussing the notions of neutrality, alterity, and transcendence of being through writing, Emmanuel Levinas's influence on Maurice Blanchot cannot be missed. Both men deny the existence of the absolute form of being, which in

\footnotetext{
${ }^{1}$ It can be argued that while taking the risk of reading a fragmented text, the reader experiences a sense of waiting for the true meaning of the work, which inadvertently forces the reader to slow down and to engage actively with the text. As a consequence, the reader reflects on the state of being and becoming of a textual product as well as of his/her role in life itself. Not the final textual product then is of importance, but rather the experience of reflection and its consequential deeper awareness of the text and of the self is the premise of Blanchot's texts. In this sense, his texts appear to say nothing, but actually saying everything.
} 
Blanchot's case translates to a denial of the existence of a fully completed text on the one hand, and the encouragement to develop a process of "thinking that goes beyond the realm of being" (Levinas 1987: 13), on the other. This leads to the recognition of a transcendental, unidentifiable, neutral essence that expresses itself via the "ambiguity of the Saying and the Said" (Critchley 1996: 114). Not the finished book or the Said is of importance, but the space that results from the ambiguity and the "interruption of language" (Sealey 2013: 441) that finds articulation in the inexpressible and unnamable. Hence, the main interest relies on something other than complete representation.

In Levinas's case, this other takes the form of the autrui, the other face that looks at and talks to me. As such it is an entity that refers to you, "the other person, [...] that each of us encounters directly, or experiences the traces of, every day" (Young 2017). This entity is an external social other, "the clearest and most potent revelation that I am not everything-that everything does not belong to me and that my consciousness does not encompass everything" (Young 2016: 2). However, this other is not one specific person. It is actually anybody other than me. Hence, it has to be understood as an unidentified and unidentifiable existence that imposes itself onto my ego's world, and when doing so, challenges and influences my understanding of selfhood. In short, this other presence, also referred to as the face of the other, "cannot be captured or grasped and is therefore, in the strictest sense of the word, incomprehensible" (Peperzak 1993: 21). It is something that transcends a defined existence with a fixed identity. It is something that simply is.

Maurice Blanchot's novellas encapsulate the presence of this other and its resulting notion of otherness in several ways. His fictional characters, for example, express themselves in seemingly empty dialogues whose sentences are often incomplete or appear in a sequence of questions that remain unanswered. Moreover, its thoughts are often fragmented and remain undeveloped, and the choice of vocabulary is repetitive triggering an overall feeling of "otherness and strangeness" (Waldenfels 2008: 63). The following dialogue between the anonymous narrator and his female interlocutor in Awaiting Oblivion exemplifies these observations well:

"He watched over the forgetting where she was leading him, by a calm movement that came from forgetting. Forgetting, forgotten. 'If I forget you, will you remember yourself?'-'Myself, in your forgetting of me.'-'But is it I who shall forget you; is it you who will remember?'-'Not you, not I: the forgetting will forget me in you, and the impersonal remembrance will efface me in you, and the impersonal remembrance will efface me from that which remembers."' (Blanchot 1997: 38)

Instead of finding answers to these questions in the text, this dialogue rather provokes additional questions in the reader: What does this dialogue, which is composed of incomplete and repetitive questions, entail? Does it focus on the forgetting of the other, of the self, or of the other as part of the self? What does the repetitious use of the verb "to forget" mean for this dialogue, for the text as a whole, and maybe even for Blanchot's entire work? What shall we not forget? What shall we remember? 
Since Blanchot leaves questions unanswered, readers often judge his writing as incomprehensible or meaningless. Literary critics, such as Donald G. Marshall and Rhys Tranter, even define Blanchot's writing as radically defective (Marshall 1986: 226). To them, the writing consists of "scattered fragments of ordinary experience" (Marshall 1986: 225), which are so difficult to understand that the resulting text seems to disappear. As a consequence, Blanchot's texts are other because they "invariably withdraw from themselves to cast doubt on their own thinking or inherited terms of reference" (Hill 2012: 143). In reference to the quote above (Blanchot 1997: 38), the text seems to call into mind the act of remembrance of one's true self, yet casts doubt on this thought by focusing on the act of forgetting of the self in relation to the other.

Like Levinas's speaking other that imposes itself onto the listener, Blanchot's fragmented text imposes itself onto the reader, demanding an ongoing reading process to discover its meaning and truth. However, due to the texts' fragmentation and abstract use of language, the reading process is obscured, and the reader becomes hostage to the engagement with the written artifact. In other words, the reader gets consumed in the everlasting "quest for the work" (Blanchot 2003: 200) implying that the reading process will never be complete because, as Levinas once stated, "the Saying (le dire) can never coincide with any Said (le dit)" (Peperzak 1993: 29).

Since the Said will always be called into question, the text's content and dimension will always surpass its reader, meaning that the engagement with the other does not necessarily lead to the discovery of the truth, but to a "higher dimension that commands us" (Peperzak 1993: 43) and that silently forces us as readers to return again and again to the written artifact and to look beyond its written surface. The outcome is an endless rereading that will always be marked by the reader's confusion, misunderstanding, and disorientation leading to an eventual breakdown or death of communication between the text and the reader.

This breakdown of communication and its subsequent silence is very characteristic of Blanchot's novellas Death Sentence, Awaiting Oblivion, and Madness of the Day. For example, in Death Sentence, the anonymous first-person narrator discloses two unrelated events. In the first part, the narrator describes his peculiar relationship with J., a woman whose medical condition confines her to bed, to excruciating pain, and to injections of morphine until she dies. In the second half of the novella, the narrator conveys his irregular encounters with his neighbor Colette as well as with the translator Nathalie and her young daughter Christina. Even though identified by name, the three women lack any further characteristic features and appear disconnected from their surroundings. Whether Colette is "crying violently" in her room, or Nathalie is described as "[finding] herself wrestling with strange feelings, in the room" (Blanchot 1978: 48, 50), neither women, nor surrounding space find further discussion. One could even say that the missing characteristics of the female character reflect the non-existing description of their apartments and vice versa. Both, woman and rooms, remain "more or less empty and neglected" (Blanchot 1978: 55).

This missing information is aligned with Blanchot's understanding of neutrality and Levinas's cognizance of the nakedness of the other. According to 
Levinas, the other's "beauty, talents, performances, roles, or functions" (Peperzak 1993: 20) are of no importance to the beholder. Only the fact that the other exists is of importance, because its simple existence signifies already that I am not everything. The revelation of any particularities of the other would lead "me away from the "absolute otherness" that is [expressed, presented, and] at stake" (Peperzak 1993: 20). Hence, neutrality is the key to maintain the notion of absolute otherness. In this particular case, otherness of the literary artifact.

The resulting lack of information prompts questions such as: Who is the narrator? Who is J.? What is her medical condition? Who are the other women? What is their relationship to each other? Or, which message does the text attempt to relate? The text itself does not answer any of these questions, just sparks them in the reader. In this sense, Blanchot's text as a whole becomes the literary manifestation of Levinas's naked face of the other that "interrupts and disturbs the order of my, ego's, world" (Peperzak 1993: 20). It imposes itself onto me, the reader, in the form of a narrative composed of an unlimited number of questions and fragments that somehow seek adherence and completion through the reading process.

In Madness of the Day, it is yet another non-identified male narrator who, in his journal-like entry, alludes to his travels, solitude, relationship to others, physical assault due to which he almost lost his sight, and the meaning of life, without ever revealing any connection between or deeper meaning of these individual components of his discourse. Instead of providing detailed information, the first-person narrator often ends his discourse with a question. He asks: "Why all that? Who was being questioned? Who was answering?" (Blanchot 1981: 1617). By doing so, he engages the reader in his monologue illustrating his "hellish unfreedom" (Wellbery 1996: 159) from life in general, and from the other to which the I is bound, in particular. In addition, through the pronunciation of questions, the narrator closes and reopens his account. He actually includes the reader in the creation of his own story, because he himself refuses to tell a story. He states unmistakably: "No. No stories, never again" (Blanchot 1981: 18).

The narrator's conscientious choice of silence then shifts the responsibility onto the reader and requests him/her to answer all the questions that have been left unanswered by the text, making the reader the speaking subject. In other words, it is "the other's command [that] commands me to command" (Thomas 2004: 115). The impossibility to complete this command results in the only outcome possible: the formulation of an endless number of questions that originate from a breakdown of communication between the text and the reader.

Awaiting Oblivion, Blanchot's most experimental narrative, generates a similar breakdown of communication. It is a story about an encounter of a man and a woman, "anonymously known as Il and Elle, respectively" (Khatab 2005: 83). At the beginning of this story that "revolves around their relationship" (Khatab 2005: 83), the woman states loud and clear: "I will not tell you everything; I will tell you almost nothing" (Blanchot 1997: 11). This contradictory statement holds true for the remaining 80 pages of the text, which Blanchot fills with a seemingly incomprehensible and empty dialogue that finds its architectural 
representation in the hotel's sparsely furnished room "reduced to the bare essentials" (Gregg 1997: x).

Here it can be argued that hotel room and conversation express a certain distance to and refusal of the material and emotional world, which already shines through in the woman's repetitive statement: "I will not tell you everything; I will tell you almost nothing" (Blanchot 1997: 11); a statement that, through its articulation of opposing concepts-everything vs. nothing-also creates a sense of ambiguity, non-comprehension, and hesitation. This hesitation and noncomprehension are fueled by additional questions that again remain unanswered: "Why do you listen to me as you do? Why, even when you speak, do you keep listening? Why do you attract in me these words that I must then say? And never do you answer; never do you make something of yourself heard" (Blanchot 1997: 4). This list of unanswered questions followed by the reproach of not making oneself heard underlines "the emptiness of the voices" (Blanchot 1997: 7) as well as the emptiness of the hotel room in which they are articulated. Moreover, it illustrates the characters' refusal to engage in a meaningful discourse.

The man's question "Why do you attract in me these words that I must then say?" (Blanchot 1997: 4), initially directed at the woman in the hotel room, becomes then a question the entire text directs at its reader. By doing so, the text imposes itself onto the reader and demands its completion through the reading process. Thus, it can be argued that the existence of the text is the revelation of the existence of the other that imposes itself on me, the reader, and that puts me in question. Hence, the narrator of each novella exposes me to the inescapable and incontrovertible demand of and answerability to the other (Young 2016), the invisible force that "regards me and speaks to me" (Peperzak 1993: 64) silently about the rewriting or completion of the fragmented text through the reading process.

As a result, it is not important what was said, but that something was said, because Levinas's "autrui me parle" (Peperzak 1993: 20) and forces me, the reader, to respond to the other, the highly fragmented text filled with "abstract words, which [evoke] nothing" (Blanchot 1997: 8). Only when interacting with the artifact, the text comes alive and brings about a subsequent set of questions that applies to all three of Blanchot's novellas: Will the reader ever be able to complete what Blanchot calls "unfinished separations' within a text" (Blanchot 1986: 86)? And if so, will the reader find the true answer for the text's immanent questions? Or does the reader rather run the risk of losing himself in the never ending fragmentation of the original text that only seems to develop towards completion during the reading process; a process that in reality actually "digresses, dissipates, dissolves, disappears" (Mellamphy 1998: 84), yet transcends into a new fragment of nothingness? In other words, are Blanchot's texts so fragmented that the reader will never be able to overcome this breakdown of communication between the text and the reader; a breakdown that is representative of the death of communication and its resulting silence? 


\section{"I will not tell you everything": The Silent Articulation of Something Other}

It cannot be denied that Blanchot's "unfinished separations" (Blanchot 1986: 86) create silence between fictional characters as well as between text and reader. However, it is only through the engagement with the (un)spoken or (un)written word that the character and the reader realize that this particular silence allows for self-questioning and self-discovery, which ultimately leads to the true meaning of the work: a better and deeper understanding of one self that results from a deep reflection on the written text. This said, Awaiting Oblivion seems to hold the key to all the questions raised above, even though the work itself allows neither its characters nor its readers to understand fully the situation and the relationships depicted. Yet, it is not the plot of the story that is of primary importance, but the active engagement with the text that allows for the development of a new form of awareness and self-consciousness through constant reflection on the textual product and the self. As a result, Blanchot's texts say nothing at first sight, but express actually everything upon reflection.

This argument finds support when looking closely at the statement: "I will not tell you everything" (Blanchot 1997: 11); a statement that indicates resistance and repression. The sentence functions as a selective vocalization of something that has not yet and never will be precisely defined. As such, the sentence utters the silent articulation of something other, something that, according to Anne McConnell, takes the characters' and readers' focus "away from the words and the narrative itself as the locus of truth, provoking [both] to search elsewhere" (2013: 175). This can only entail looking for meaning outside of the actual text and its immediate surrounding and to take Blanchot's work for what it is: a literary manifestation of Levinas's face of the other that looks at me, speaks to me, and imposes itself on me. It is the face of the other to which I, the reading subject, am drawn. Since my engagement with the other, in this case Blanchot's textual surface, "is not attached to a particular feature of this other but to [its] entrance into my world, all others oblige me as much as this one" (Peperzak 1993: 31). This means that this other, as already stated, cannot be reduced to one singular entity or, in our case one singular text, but should rather be understood as something that can have multiple forms and that may transcend physical existence.

Searching for the textual implications outside of the text then forces us, the readers, "to wait outside our own waiting, leaving us nothing more to await" (Blanchot 1997: 14) than ourselves. When this point is reached and the reader realizes that the text cannot answer the questions it triggers, the generated other becomes internalized, because it then points towards me, the internal object to which the self or the speaking subject-I-is inevitably linked (Reuber 2014). On the one hand, it becomes an expression of negation of the textual external other. On the other hand, it has to be perceived as an affirmation of the self, the psychological entity that is constructed of the I-the speaking subject-and me-the object-the internal other expressing in its own incomprehensible language the needs, desires, hopes, fears, etc. that affirm singularity and authenticity of the self. The text's imposed demand on the readers to act becomes the readers' enactment 
of their own desires to react. Hence, it is only through the interaction with the external other that the internal other contests the state of being, simply because it demands a reevaluation of "both self and the totality of other things" (Benjamin 1997: 17). This leads to the conclusion that only via the engagement with the other we learn "what we cannot learn from ourselves [alone] and develop a better understanding of both the other and the self" (Waldenfels 2008: 68).

Therefore, whether the object is external or internal, it is inevitably linked to the subject, which defines itself through "its relationship with the object" (Scharff 1992: 23). It is this link that fosters "the comprehension of who "we" are" (Hewson 2011: 19) and, consequently, of who we become. In other words, the self is "related and linked to the other from which it is separated," but from which "it is unable to escape" (Peperzak 1993: 53), whether the other is internal or external.

Maurice Blanchot illustrates this inextricable relationship between the self and other through the interplay between characters, their interaction with each other, and the breakdown of communication and human relationships. In this sense, he expresses the opposition between the self and the external other-youwhose relationship with one another is expressed and practiced through language. He further exemplifies this relationship via the absence of speech and the acknowledgement of the innermost thoughts that shall not be uttered and recognized, but rather repressed. Blanchot's characters are ruled by their non-recognition of the dynamic relationship consisting between the subject-Iand the object-you and me-the exterior and interior other that opposes and challenges the self.

Whether confronting the exterior or interior other in a social setting or in a one-on-one conversation, the reaction to the unknown opposing and imposing on the self is fear. It is the fear of the other that lays claims on to the self and, by doing so, challenges one's self-conception to the extent that the other seems to dominate the self and eliminate the one thing one once thought to know (Critchley 1996). It is the fear of a violent change that is imposed onto the speaking subject via the destructive function of language. As Ullrich Haase and William Large point out in their monograph on Maurice Blanchot, "the other approaches me in speech as the stranger and as the unknown, who comes to me from outside [or inside] and who, in addressing me, undermines my self-repose and certainty" (2001: 76).

Speech in this sense needs to be understood as a verbal and visual way of communication to which the self responds in either a verbal, visual, or tactile way. This interchange between self and other is constant and serves as a reminder of invasion of personal space, as well as a reminder of reality that everything belongs to both of us, you and me. As a consequence, reality "becomes genuinely 'exterior'-and at the same time, I become genuinely 'interior,' because I am now truly differentiated from the external world" (Young 2016: 2). This insight leads to the realization that I myself am other, other to you as well as to what I thought constituted my own self, because the "I" is far from being complete; it is transcendental, thus, constantly developing and becoming something other.

From this insight follows that "I am related to many others who urge me with equal absoluteness to dedicate myself to them" (Peperzak 1993: 168), who hold 
me responsible for them, and who challenge the notion of who I think I am. Confused and fearful, I retrieve from the other socially, emotionally, and also verbally, because-using now the narrator's words from Awaiting Oblivion "[w]hen I speak to you, it is as if the entire part of me that covers and protects me abandoned me and left me exposed and very vulnerable" (Blanchot 1997: 10).

Consequently, not everything can or should be expressed, but rather remain unarticulated, suppressed, and held back. This kind of negation and suppression leads, of course, to yet another breakdown of communication. Silence and solitude are again its subsequent results. However, this self-imposed restraint also allows the writer to produce "meaningful prose" (Blanchot 1986: 332), because through saying nothing, the writer, reader, speaker, and listener are able to preserve the distance between themselves and the other and to maintain singularity and authenticity of thought and being. Only then is there no risk of "reducing that which is named to the level of banality" (Kleinberg 2005: 217) or imposing one's self onto the other or vice versa.

Nevertheless, the phrase "I will not tell you everything" (Blanchot 1997: 11) also expresses the opposite, namely that something will be revealed. As a result, the statement creates the sense of hesitation and waiting; a waiting for clarification, for resolution, for everything "what is outside" (Blanchot 1993: 304) of our knowledge, for everything that belongs to the silently implied unknown. Therefore, the sentence "I will not tell you everything" (Blanchot 1997: 11) addresses the lack of the understanding of le tout. It alludes to "what is still to be attained and of what is still to be known" (Blanchot 1997: 11). It addresses an everlasting waiting that is "interminable and inescapable, without culmination nor redemption" (Hill 2012: 131), a waiting that becomes an experience itself.

In my understanding of Blanchot, the statement silently pronounces an act of waiting for the understanding of one's self in relation to the other at the same time that it negates an existing ideal or absolute form of being. ${ }^{2}$ Even though this statement applies to all three of Blanchot's novellas discussed in this article, the act of waiting and the negation of an existing ideal manifests itself differently in each one of them.

In his novella Death Sentence, waiting is manifold: Whereas J. awaits alleviation of pain through death, the anonymous narrator seems to await the extinction of the female other, in order to find his voice to tell his story. It seems that the narrator's sudden act of enunciation results from his processing of J.'s severe illness and subsequent death, thus, through the waiting for the passing of the other. In Awaiting Oblivion, the narrator's waiting for the understanding of his self in relation to the other expresses itself in the unsuccessful act of communication that is characterized by long lists of unanswered questions creating a void between the interlocutors. This waiting for deeper knowledge is though brutally withdrawn from the text when stating: "I will tell you almost nothing" (Blanchot 1997: 11). These words invalidate everything that the character and the

\footnotetext{
${ }^{2}$ This is similar to Hegel's notion of absolute idealism according to which, "only mental entities are real [...] [and] physical things exist only in the sense that they are perceived" (www.philosophypa ges.com/dy/i.htm\#idlm). In other words, only mind and spirit represent the ultimate reality and form of being.
} 
reader once awaited, namely the possible understanding of the other and the understanding of me in relation to you. In addition, it leads to the painful awareness that we are, as Blanchot says, "waiting for ourselves without ourselves, [...], leaving us nothing to await" (Blanchot 1997: 14). In other words, we are kept prisoner in a never-ending and unsuccessful process of waiting to ever understand ourselves as well as our relation to the other. This then leads to the realization that we are left in a vast void in which we are separated by everything that we do not want to articulate (Blanchot 1997: 20).

This void and "solitary waiting" (Blanchot 1997: 14) for and through the other is nowhere better expressed than in The Madness of the Day, a story whose male narrator reflects upon identity, activism, resistance, and otherness. Statements such as "In haste, I would rid myself of myself. [...] I reduced myself to them. [...] [and] I'm a special case. Special if you act-never, if you let others act" (Blanchot 1981: 14-15) articulate clearly the interconnectedness of the self and the other. In addition, these statements oppose the absolute form of being and point towards the respective notion of self-determination and identification through the other. The fact, however, that Blanchot's narrator ends his account refusing to ever tell another story implies that he favors silence over communication and distance from over closeness to the other. Since the self only develops through the interaction with the other, his statement-"No stories, never again" (Blanchot 1981: 18)indirectly implies the narrator's lack or negation of self-consciousness.

\section{Confinement to and Recitation of Otherness}

This resulting insufficient understanding of the self is at the heart of all three of Blanchot's texts. In all three novellas, his desubjectivized narrators are incapable of providing either a complete portrayal of themselves or of the situations they seek to resolve. Characters and narrator seem to be "stuck in living spaces-houses, apartments, infernal institutions, [and] hotel rooms" (Kaufmann 2005: 126) that are sparsely furnished. Whether in J.'s sickroom in Death Sentence, the narrator's cold and modest hotel room in Awaiting Oblivion, or the narrator's unidentified institution in The Madness of the Day, the stories' characters all relive similar situations, which are characterized by a lack of detail, a lack of communication, and, most importantly, a lack of understanding of the situation, of the other, as well as of themselves. In The Madness of the Day, this lack of detail and absence of comprehension expresses itself in the articulation of non-coherent paragraphs ranging from the depiction of the narrator's education, to his travels, love-life, trials, constant affirmation of being asleep, to a range of questions such as: "I asked myself, wasn't I sad, hadn't I felt my life breaking up?", What was I before?", "Who am I? ", "Who was answering?" (Blanchot 1981: $7,8,10,17)$.

These questions remind the reader of the incoherent dialogue of the man and woman in the hotel room in Awaiting Oblivion. Here the text opens with "Who is speaking?" (Blanchot 1997: 1), followed by "Why do you listen to me as you do?", "Why do you attract in me these words that I must then say?" or "What could I do?" (Blanchot 1997: 4, 7). As in The Madness of the Day, characters in Awaiting 
Oblivion do not find answers to these questions within the text. They are left waiting and wondering about "the meaning of this whole story" (Blanchot 1997: 11), and engage in negative discourse, which seems as silent and empty as the text itself.

In this sense, narrator and fictional characters mirror Blanchot's defective writing and become confined to the space of textual otherness that they are unable to leave (Blanchot 1997: 13). However, it is within this confinement that text and characters engage in Blanchot's double parole and pronounce everything and nothing that they always wanted to say. As mere placeholders for the face of the other, narrator, character, and textual surface put forth a discourse whose message Blanchot re-cites ${ }^{3}$ in all three novellas, namely: "I will tell you almost nothing" (Blanchot 1997: 11). It is a message that exemplifies the quintessence of the author's understanding of the textual artifact as a representation of the Levinasian face of the other, namely that "we are concerned with saying, not with the said" (Waldenfels 2008: 68).

With this in mind, the reader stops searching for detailed information about any of Blanchot's fictional characters. In Death Sentence, it seems irrelevant to know what J. was suffering from or why she was longing for the beginning or end of dying. In Waiting for Oblivion, it is unimportant to understand the relationship between the anonymous narrator and his female counterpart at the hotel. In Madness of the Day, it is no longer necessary to comprehend what triggered the narrator's acute but distorted perception of his surrounding that "assailed [him] irrationally, without control, without purpose" (Blanchot 1981: 11) and that allowed even the light of the day seem to go mad.

What is important is the realization that the breakdown of understanding of the textual other not only closes but, at the same time, instigates "the resurrection, or the starting over, or the living beyond the life of the narrative" (McConnell 2013: 196). It (re)opens the récit through its re-telling. In other words, it allows the breakdown of understanding to arise "out of the excessive space that precedes it" (McConnell 2013: 197) and to continue in the repetitive attempts to make one's self understood through a highly fragmented and elliptic discourse. This realization exemplifies "the power of language to negate the immediacy of things" (Haase and Large 2001: 31) on the one hand, and the consequential never-ending expression of ideas, on the other.

It is this present absence or absent presence of language that negates any "extra-linguistic reality" (Haase and Large 2001: 31) and produces self-questioning. Consequently, it exemplifies that "the search for the truth is not uniquely a discovery of the exterior but a transcendence or [...] a 'transcendence' toward a dimension that commands us" (Peperzak 1993: 43). As such, Blanchot's work allows for l'expérience-limite to occur: an experience that defines a complex relation "that man encounters when he has decided to put himself radically in

\footnotetext{
${ }^{3}$ The etymological meaning of the verb "to recite" derives from the old French verb réciter which is a derivative of the Latin verb recitare meaning "read aloud, read out, repeat from memory, declaim," Online Etymological Dictionary (http://www.etymonline.com/index.php)?allowed_ in_frame $=0 \&$ search=recite\&searchmode=none $>$. The verbs suffix "re" indicates a repetitive action, a re-telling, re-summoning of something.
} 
question" (Blanchot 1993: 203). This relation has to be understood as an opportunity to experience authenticity and singularity on the physical, psychological, emotional, and cognitive level via one's engagement with the other through language: provided that one understands that the discourse with the other does "not reveal anything, because everything [has] long since been revealed" (Blanchot 1981: 17). Consequently, the statement: "I will tell you almost nothing" (Blanchot 1997: 11).

The antithetical statement, "I will tell you almost everything; I will tell you almost nothing" (Blanchot 1997: 11) then illustrates well the double parole of Blanchot's work. It is a parole that expresses the necessity but also the insufficiency of the spoken and written word to help define the self in relation to the internal and external other. It is a parole that "has linked the presence of negation to affirmation" (Benjamin 1997: 18) of speech and being, as well as to the recognition and negation of "the precise, balanced speech of man" (Marshall 1986: 226) whose notion of selfhood will never be fully known but will always remain in the making.

Exploration and Understanding of the Self and the other via the Neutrality of Language

This notion of the unknown, of the state of self-unawareness, and of the lack of self-consciousness, manifests itself also in the use of subject pronouns in the work. The ease with which the narrative voice in the three novellas substitutes or interchanges the first-person subject pronoun je with the third-person subject pronoun $i l$ or elle as well as with the first-person plural subject pronoun nous supports the argument previously made, namely that the narrative voice is desubjectivized and unable to speak for him/herself.

It can even be argued that if je can be substituted by nous as is predominantly the case in Awaiting Oblivion, the self is no longer different from the other, resulting first in the absorption of the other, second, the consequential objectidentification with the other, and third, the ultimate transformation of the self into the other and vice versa. This implies that the text no longer shows a real dialogue between the individual interlocutors (Blanchot 1997: 25), but rather conflates voices until one voice substitutes the other. The result is the complete loss of identity, on the one hand, and the gain of anonymity, on the other. As my subjectivity becomes "interrupted by the alterity" (Sealey 2013: 435) of the text and its desubjectivized voice, my message becomes your message and one is no longer able to distinguish between who is being asked and who is asking. As roles between self and other then become interchangeable, the message loses its singularity and becomes an expression of either everything or nothing, combining the different voices initially heard into a single one: our message. It is then that the two entities become one, or as Blanchot says: "the one is the other" (1997: 26).

In Blanchot's texts, this particular message turns into an utterance of fragments which eventually results in what Manola Antonioli calls "la discontinuité absolue des blancs des pages" (1999: 33). This discontinuity leads to the textual 
representation of a narrator who is incapable of establishing himself "comme narrateur et sujet de son proper récit" (Antonioli 1999: 39). Consequently, the first-person narrator in question becomes a narrator who, like the text itself, appears fragmented, incoherent, and lost in the overall "impersonality of the work" (McConnell 2013: 26). This dissolution of identity and singularity finds its pendant in the sparsely furnished bedrooms or hotel rooms, whose predominant characteristic is emptiness even when "full of strangers" (Blanchot 1978: 18).

The fact that the narrator in Death Sentence declares that "everything about that room, plunged in the most profound darkness, was familiar to [him]" and that even though empty that room held "the most intense life" (Blanchot 1978: 67) illustrates the coexistence of absence and presence, of silence and noise, of emptiness and fullness. More so, it expresses the coexistence of the speaking subject-I-and the listening object-me-within the room of existence. As such, these words exemplify the "very divide between the interiority of the self and exteriority" (Sealey 2013: 437), the divide between the self and the other as well as the time in between being and becoming.

It is in "these close quarters, where the words she said could signify nothing other than this confinement" (Blanchot 1997: 13), and where the exploration, assimilation, and exchange of the self and the other takes place, allowing the character and narrator to disappear and the reader to enter the work. It is in this place, where the non-identified female character in Awaiting Oblivion asks her male counterpart, "Do you want to separate yourself from me? But how will you go about it? Where will you go?" (Blanchot 1997: 13-14). Like so many other questions before, these remain unanswered, leaving the voices of the characters "ring out in the immense emptiness" (Blanchot 1997: 7) of the empty place.

But why is it that the interlocutor chooses one more time silence as a response? The answer to this question is twofold. First, whereas earlier the other transferred the responsibility to find answers to the questions onto the reader out of convenience, thereby commanding the reader to complete the literary text while assuming the role of the speaking subject, now the silence of the male narrator is rather symptomatic of his lack of self-knowledge and selfawareness, as well as his shortcomings in understanding the other in relation to the self. The narrator in Awaiting Oblivion simply does not know the answers to the questions asked by his female interlocutor. Moreover, he is not even aware that he is alone in the hotel room, and that the two different voices heard actually both belong to him, "the male lead, also a writer, and a woman, the mysterious, unknowable, unseizable figure of the dehors, the outside" (Gregg 1997: xi), the narrator's unrecognizable other.

Second, whether resulting out of convenience or an illustration of an insufficiently developed understanding of the self, the occurring silence also functions as a negation of the other. As such, the unanswered questions serve as a means of attestation and preservation of selfhood. It is Blanchot's double parole at its finest; a parole that is not only a speech of absence or silence, but also a non-verbal (silent) reference to the non-existence of an absolute being on the one hand, and an affirmation of "a conception of singularity that is linked to authenticity" (Benjamin 1997: 13), on the other. It becomes obvious that at a 
time where speech expresses itself in silence and negates the other, the oral speech or the written text reveals something "that is beyond reach (of the one who says it as much as the one who hears it) " (Blanchot 1993: 212). It is something "that Blanchot calls the 'relation to the unknown' and that finds expression in the silence of speech" (Haase and Large 2001: 76). As such, it is something that allows for the "always eternally becoming" (Mellamphy, 1998: 85) of being that is far from its ideal or absolute form, but which, at the same time, is always part of the one thing that becomes, our self.

Without a definite and absolute being, there is no definite or absolute speech, thus, there is neither absolute truth nor lie attached to what is said. From this we can conclude that our speech is nothing else than "an undecided movement between what [we] cannot possibly do and what [we] can't help doing" (Smock 1999: 1041), namely expressing our thoughts and forcing them onto the other. It necessarily follows that Blanchot's double parole is a speech of silent and powerful possession that even though not uttered loudly, represents a loud cry from within; a cry that runs through all three works and that seems to be uttered by "the mouth of someone [the narrator] did not know" (Blanchot 1978: 28). It is a cry that, over time, takes on such a fragmented and regressed form that it is too difficult to be understood by oneself or by the outside world. It is a cry that we as readers have to set in relation to our own self, as it is and always will be "subjected to and unable to escape from me being regarded, touched, and disposed of by my encounters" (Peperzak 1993: 28-29) with the other.

As a consequence, the characters in Blanchot's texts seem to remain silent, "with nothing left to say, [and] the work ultimately becomes the speech of itself" (Marshall 1986: 227). It becomes the testimony of otherness expressing itself in the form of questions that are only answered through the reading process of the récit. Hence, as the narrator in Death Sentence states: "What is extraordinary begins at the moment I stop" (Blanchot 1978: 53). But what begins at the moment the narrator stops narrating? What is hiding behind the face of the other, Blanchot's story that is nothing else than the event that it tells and re-tells?

It is the intrusive presence of what Emmanuel Levinas calls the il y a: "the anonymous and impersonal current of being" (Kleinberg 2005: 218) in which the everyday world dissolves, disappears, and becomes. It is an entity of no specific form or clarity, an allusive and infinite neutral existence "divorced from the principle of individuation" (Large 2002: 136) that lurks around like an everlasting shadow invading and disarming the self by the simple fact that there is. As such, Levinas's il y a "constitutes a lack or deficiency of the presence of being" at the same time that it represents a "justification for seeking a beyond of being" (Bautista 2012: iv).

In regard to Blanchot's writing, the notion of the il y $a$ then hides behind the voice of the desubjectivized narrator and the non-identifiable characters. It expresses itself through the works' negative discourse that is characterized by an adhesive string of words or ideas representing a fragmented picture of a whole; something that strives for completion via the "neutrality of language" (Haase and Large 2001: 80). It is an indefinable force that hides behind the face of the other and that puts the self into question, forces it to reflect, to evaluate, and to assess its 
current form of being and, consequently, its becoming. Hence, the existing entity of the il y $a$ challenges one's identity via its body, face, and language.

When not being able to define this "obscure invasiveness against which there is neither refuge nor recourse" (Toumayan 2004: 151), the narrator of Death Sentence for example reacts with terror and refers to the il y $a$ as something that "I am no longer able to speak of" (Blanchot 1978: 30). He describes it as something whose infinite character cannot be expressed via the limited set of words simply because the il y a designates "the time of a "between," the no longer and the not yet" (Sealey 2013: 437). This in-between state of what once was and what will be finds exemplification in J.'s continuous suffering and fight for her life, on the one hand, and the narrator's respective fight for the right words to convey to the reader his perception of the situation, on the other. J.'s physical and the narrator's intellectual suffering, then go hand in hand, yet even have the same outcome. J. dies, and the narrator turns silent after informing the reader: "I don't want to say anything. [...] I am no longer able to speak of it" (Blanchot 1978: 30). "It" referring to the il $y a$, then has to be understood as an indefinable absent presence as well as a present absence. It is something that is intricately linked to Blanchot's defective ré-cit.

While hiding behind the face of the other-Blanchot's textual artifact-the presence of the Levinasian il y $a$ is symbolic for "a temporality of incessant return rather than to one defined in terms of an absolute beginning and end" (Gregg 1994: 29). It is the readers' constant reminder of the never-ending text, ensuring an everlasting waiting and "quest for the work" (Blanchot 2003: 200) as well as for a complete understanding of the self. As long as the reader is not able to fully understand him-/herself or is incapable of finding him-/herself "as a self with power" (Sealey 2013: 436), the il y a remains an ever-present oppressive force that cannot be explained. Hence the exclamation: "I am no longer able to speak of it" (Blanchot 1978: 30). Repressed in thought, the il y a remains unarticulated, but present. It hides behind the narrator's filled void, behind his fragmented speech, the face of the other. Hence, the il y a closes and reopens Blanchot's récits and maintains the quest for the true understanding of the self, which is no longer the same, but not yet redefined and fully understood. It is the double parole of Blanchot's texts, which allows for the discovery of the hidden message of the writer's seemingly void text: the silent but violent cry for reconciliation of the self and the other, of being and becoming.

\section{Conclusion}

In conclusion we can state that this silent cry for reconciliation of self and other, of being and becoming, runs through all three of Blanchot's novellas discussed in this article. It is a cry that results from the otherness and strangeness of the literary work manifesting itself in its fragmented structure, lack of visualization and detail, and a seemingly empty discourse between the fictional characters and a desubjectivized narrator. This cry is representative of Blanchot's understanding of the incompleteness of the written document and the resulting 
quest for the work on the one hand, and the quest for a better and deeper understanding of the self and of the other.

As illustrated throughout the analysis, this quest starts with the reading process demanding the reader's constant engagement with the text. However, this quest actually continuous beyond the textual boarders due to the fact that the fragmented text triggers an endless number of questions without ever answering them. As a result, the written artifact imposes itself onto the reader and demands completion of the text through the reading process. By doing so, it challenges the reader to reflect on the text, but also on his/her perceptions and viewpoints throughout the reading process. Through constant reflection on the textual artifact, the reader engages not only with the written word, but more importantly, with the questions it triggers leading to the understanding that not what was said is of importance, but that something was said, something that the reader needs to reflect on and process. It is then the space that results from what was said and the imposition that results from it that challenges the reader's understanding of self. As such, Blanchot's texts take the form of the unidentifiable Levinasian face of the other behind which is and hides something; something that commands us, readers, to command and to take action, to seek self-awareness, to develop selfconsciousness, and to take the role of the other, the speaking text.

\section{References}

Antonioli M (1999) L'Ecriture de Maurice Blanchot. Fiction et Théorie (The Scripture of Maurice Blanchot. Fiction and Theory). Paris: Editions Kimé.

Bautista St. (2012) Ontology in Emmanuel Levinas's Philosophy. Unpublished doctoral dissertation, Loyola University of Chicago. Retrieved from https://bit.ly/2mneT4g. [Accessed 10 June 2016].

Benjamin A (1997) Figuring Self-identity: Blanchot's Bataille. In J Steyn (Eds.), Other than Identity. The Subject, Politics, and Art, pp. 9-31. Manchester and New York: Manchester University Press.

Blanchot M (1978) L'Arrête de mort (Death Sentence). Translated by L Davis. New York: Station Hill Press.

Blanchot M (1981) La folie du jour (Madness of the Day). Translated by L Davis. Barrytown, NY: Station Hill Press.

Blanchot M (1986) L'écriture du désastre (The Writing of disaster). Translated by A Smock. Lincoln: University of Nebraska Press.

Blanchot M (1993) L'Entretien infini (The Infinite Conversation). Translated by S Hanson. Minneapolis: University of Minnesota Press.

Blanchot M (1995) La Part du feu (The work of fire). Translated by C Mandell. California: Stanford University Press.

Blanchot M (1997) L'Attente l'oubli (Awaiting oblivion). Translated by J Gregg. London: University of Nebraska Press.

Blanchot M (2003) Le Livre à venir (The book to come). Translated by C Mandell. California: Stanford University Press.

Critchley S (1996) Il y a-Holding Levina's hand to Blanchot's fire. In C Bailey Gill (Eds.), Maurice Blancho: the Demand of Writing, pp. 108-122. New York: Routledge.

Davies P (1996) The work and the absence of the work. In C Bailey Gill (Eds.), Maurice Blancho: the Demand of Writing, pp. 91-107. New York: Routledge. 
Gregg J (1994) Maurice Blanchot and the literature of transgression. New Jersey: Princeton University Press.

Gregg J (1997) Introduction. L'Attente l'oubli (Awaiting oblivion), pp. vii-xvii. Translated by J Gregg. Lincoln and London: University of Nebraska Press.

Haase U, Large W (2001) Maurice Blanchot. London and New York: Routledge.

Hewson M (2011) Blanchot and literary criticism. New York: Continuum International Publishing Group.

Hill L (2012) Maurice Blanchot and fragmentary writing. a change of epoch. New York: Continuum International Publishing Group.

Kaufmann E (2005) Midnight, or the intertia of being. In L Hill, B Nelson, DD Vardoulakis (Eds.), After Blanchot: Literature, Criticism, Philosophy, pp. 123-136. Newark: University of Delaware Press.

Khatab R (2005) Timelessness and negativity in Awaiting Oblivion: Hegel and Blanchot in Dialogue. Colloquy 10: 83-101.

Kleinberg E (2005) Generation existential. Heidegger's philosophy in France 1927-1961. Ithaca: Cornell University Press.

Large W (2002) Impersonal existence. A conceptual genealogy of the "There Is" from Heidegger to Blanchot and Levinas. Angelaki. Journal of the Theoretical Humanities 7(3): 131-142.

Levinas E (1987) Collected Philosophical Papers. Translated by A Lingis. The Hague: Martinus Nijhoff.

Llewelyn J (2008) Levinas and language. In S Critchley, R Bernasconi (Eds.), The Companion to Levinas, pp. 119-138. Cambridge, UK: Cambridge University Press.

Marshall DG (1986) The necessity of writing death and imagination in Maurice Blanchot's L'Espace Littéraire. Boundary 2(14): 225-236.

McConnell A (2013) Approaching disappearance. London: Dalkey Archive Press.

Mellamphy D (1998) Fragmentality (thinking the fragment). Dalhousie French Studies 45: 83-98.

Peperzak A (1993) To the Other. An Introduction to the Philosophy of Emmanuel Levinas. Indiana: Purdue University Press.

Reuber A (2014) In Search of the Lost Object in a Bad Place: Stephen King's Contemporary Gothic. In P Simpson, P McAleer (Eds.), Stephen King's Contemporary Classics. Reflections on the Modern Master of Horror, pp. 101-116. Lanham, MD: Rowman \& Littlefield.

Scharff DE (1992) Refinding the object and reclaiming the self. New Jersey: Jason Aronson Inc.

Sealey K (2013) The "Face" of the Il y $a$ : Levinas and Blanchot on impersonal existence. Continental Philosophy Review 46(3): 431-448.

Smock A (1999) Tongue-tied Blanchot, Melville, des Forêts. Modern Language Notes 114(5-Comparative Literature Issue): 1037-1061.

Thomas EL (2004) Emmanuel Levinas: ethics, justice, and the human beyond being. New York and London: Routledge.

Toumayan A (2004) Encountering the Other. The Artwork and the Problem of Difference in Blanchot and Levinas. Pittsburgh, Duquesne University Press.

Young B (2016) An Introduction to Levinas. Retrieved from https://bit.ly/2kwIyaQ. [Accessed 15 December 2016].

Young B (2017) Meaning of "The Face of the Other". In The Face of the Other. Retrieved from https://bit.ly/2moYFrn. [Accessed 15 December 2016]. 
Waldenfels B (2008) Levinas and the face of the other. In S Critchley, R Bernasconi (Eds.), The Cambridge Companion to Levinas, pp. 63-81. Cambridge, UK: Cambridge University Press.

Wellbery DE (1996) Exercises on The Madness of the Day. Proper Names. Translated by MB Smith. California: Stanford University Press. 
